\title{
Peran Komitmen Organisasional sebagai Variabel Mediasi pada Pengaruh Budaya Organisasi terhadap Organizational Citizenship Behavior
}

Submitted Date:

8 April 2021

Politeknik Negeri Ujung Pandang

Accepted Date:

serpian@poliupg.ac.id

6 Mei 2021

Suggested Citation:

Arumi, M. S., Aldrin, N., \& Murti, T. R. (2019). Effect of Organizational Culture on Organizational Citizenship Behavior with Organizational Commitment as a Mediator. International Journal of Research in Business and Social Science (2147- 4478), 8(4), 124-132. https://doi.org/10.20525/ijrbs.v8i4.274

Abstract:

This research aimed to examine the indirect effect of organizational culture on organizational citizenship behavior (OCB) through organizational commitment as the mediating variable. Formulation of the problem in this research attempted to know about what organizational commitment that can mediate the effect of organizational culture on OCB. The path analysis was used to examine 80 respondents. The sample collection was retrieved by asking employees from each main branch banks to spread out the questionnaires. Researcher deployed 103 questionnaires yet only 86 questionnaires was returned and 80 questionnaires could be examined. These variables had been previously verified in BNI life Regional Makassar. This research concerns on the problems of the high rate of employee turnover in BNI life regional Makassar. Every year, many employees decide to resign from the bank. Besides, this research was based on the research gap, the different results of research by Giri, Nimran, Hamid, Musadieq (2016), and Meijen (2007). A study by Giri, Nimran, Hamid, Musadieq (2016) showed that there are the significant impacts of organizational culture on organizational commitment. In contrast, the result of research by Meijen (2007) revealed that there was no impact on the variables. The result of this research found that there is an indirect impact between organizational cultures on organizational citizenship behavior (OCB) through organizational commitment as the mediating variable. The conclusion is the strategic decision making related to human resource development must consider organizational culture.

Keywords: Organizational Citizenship Behavior, Organizational Commitment, Organizational Culture

Abstrak:

Penelitian ini bertujuan untuk menguji pengaruh tidak langsung budaya organisasi terhadap organizational citizenship behavior (OCB) melalui komitmen organisasional sebagai variabel mediasi. Rumusan masalah dalam penelitian ini berusaha untuk mengetahui apakah komitmen organisasional mampu memediasi pengaruh budaya organisasi terhadap OCB. Penelitian ini menggunakan path analysis dengan menguji 80 responden. Pengumpulan sampel dilakukan dengan cara meminta seorang karyawan pada setiap kantor cabang utama untuk menyebarkan kuesioner. Peneliti menyebar 103 kuesioner, namun yang kembali hanya 86 kuesioner, dan hanya 80 kuesioner dapat diolah. Variabel-variabel tersebut telah diuji di BNI life Wilayah Makassar. Penelitian berfokus pada permasalahan tingginya perputaran karyawan di BNI Life. Setiap tahunnya terdapat banyak karyawan yang memilih untuk keluar dari perusahaan tersebut. Selain itu, penelitian ini juga berdasar pada research gap, perbedaan hasil penilitian yang ada pada penelitian Giri, Nimran, Hamid, Musadieq (2016) dengan Meijen (2007). Penelitian Giri, Nimran, Hamid, Musadieq (2016) menunjukkan pengaruh signifikan budaya organisasi terhadap komitmen organisasional. Berbeda dengan penelitian Meijen (2007) menunjukan tidak ada pengaruh pada pengujian variabel yang sama. Hasil penelitian ini menunjukkan bahwa terdapat pengaruh tidak langsung antara budaya organisasi terhadap OCB melalui komitmen organisasional sebagai variabel mediasi. Kesimpulannya yaitu pengambilan keputusan strategis terkait pengembangan sumber daya manusia harus mempertimbangkan budaya organisasi.

Kata Kunci: Budaya Organisasi, Komitmen Organisasional, Organizational Citizenship Behavior

JEL Classification: 015 


\section{Latar Belakang}

Setiap perusahaan berusaha menciptakan budaya organisasi yang kuat, sebagai fondasi dalam mempersiapkan sumber daya manusia yang siap bekerja untuk perusahaan. Organizational culture has been identified as an important intangible resource and a barrier to imitation with powerful effects on performance (Joseph \& Kibera, 2019). Budaya organisasi yang kuat dapat dilihat dari perilaku karyawan yang bukan hanya sekedar melaksanakan pekerjaannya tapi juga dapat memberikan inovasi untuk perusahaan. Inovasi yang muncul dari karyawan kaitannya dengan pekerjaan dalam perusahaan mempunyai banyak bentuk, salah satunya adalah perilaku kreatif dalam menyelesaikan pekerjaan, efisien dan efektif.

Budaya organisasi dalam perusahaan merupakan faktor penting untuk merealisasikan rencana-rencana strategis pengembangan sumber daya manusia, seperti lahirnya komitmen organisasional karyawan untuk loyal dalam bekerja dan mampu berkarya dalam perusahaan. Dalam penelitian Momeni, Marjani, dan Saadat (2012) menjelaskan adanya hubungan yang kuat antara budaya organisasi dengan komitmen organisasional. Begitupun dalam penelitian Habib, Saira, Amjad, Sana, dan Muhammad (2014) menemukan bahwa budaya organisasi memberi kontribusi positif terhadap pengembangan sumber daya manusia, budaya organisasi yang kuat sangat membantu karyawan baru dalam mengadopsi budaya organisasi itu sendiri dan membantu karyawan baru memiliki keunggulan kompetitif.

Dalam penelitian tersebut juga menjelaskan adanya pengaruh yang cukup kuat antara budaya organisasi dengan komitmen organisasional, di mana budaya organisasi yang kuat mampu meningkatkan komitmen organisasional. Budaya organisasi dianggap kuat ketika sebagian besar karyawan memegang keyakinan dan nilainilai yang sama sebagai kepedulian terhadap organisasi (Shahzad, Luqman, Khan, dan Shabbir, 2012). Tidak mengherankan apabila banyak organisasi yang menyusun strategi dan menginvestasikan banyak uang dalam membangun budaya yang kuat.

Budaya organisasi dan komitmen organisasional dalam perusahaan mengusahakan lahirnya karyawan yang mempunyai perilaku ekstra peran, yaitu perilaku dengan kesadaran untuk berbuat melebihi apa yang menjadi tanggung jawabnya. Perilaku tersebut dikenal dengan organizational citizenship behavior (OCB). Perilaku OCB dijelaskan oleh Luthans (2005: 251) bahwa individu yang menunjukkan OCB memperlihatkan kinerja lebih baik. Chiu (2006) menunjukkan bahwa budaya organisasi mempunyai hubungan yang kuat dengan OCB. Robbins dan Judge (2015: 40) menjelaskan bahwa organisasi yang sukses membutuhkan karyawan yang akan melakukan lebih dari sekedar tugas biasa mereka yang akan memberikan kinerja yang melebihi harapan.

Perusahaan yang sedang menanamkan budaya organisasi yang kuat pada setiap karyawannya adalah BNI Life. Budaya organisasi yang dirumuskan oleh BNI Life Insurance termaktub dalam people, product, process (3P), Synergy, Segmented Sales, Service Standard (3C), dan Customer Focus, Compliance, Cost Effectiveness (3S). Selain itu, BNI Life Insurance sejak 2011 menjadikan kepuasan kerja karyawan sebagai salah satu poin dari internalisasi nilai organisasi (BNI Life Annual Report, 2011). Namun penguatan budaya tersebut tidak dibarengi dengan komitmen organisasional karyawan. Tingginya perputaran karyawan di BNI life memperlihatkan bahwa terdapat masalah komitmen organisasional dalam perusahaan tersebut. Turn over dalam perusahaan terjadi lazimnya karena karyawan mempunyai preferensi pekerjaan lain.

Penelitian ini juga berdasar pada research gap, perbedaan hasil penilitian yang ada pada penelitian Giri, Nimran, Hamid, Musadieq (2016) dengan Meijen (2007). Penelitian Giri, et. all (2016) menunjukkan pengaruh signifikan budaya organisasi terhadap komitmen organisasional. Berbeda dengan penelitian Meijen (2007) menunjukan tidak ada pengaruh pada pengujian variabel yang sama.

\section{Kajian Literatur}

\section{Budaya Organisasi}

Budaya organisasi selalu merepresentasikan bagaimana interaksi atau bentuk sosialisasi individu dalam sebuah kelompok. Sosialisasi organisasi merupakan serangkaian aktivitas yang secara substantif berdampak kepada penyesuaian aktivitas individual dan keberhasilan organisasi, antara lain komitmen, kepuasan dan kinerja (Nelson, Young \& Lunberg, dalam Sopiah, 2008). Menurut Edgar Schein (2004) budaya organisasi dapat didefinisikan sebagai:

"Pola asumsi dasar yang dipelajari oleh sebuah organisasi terkait dengan penyelesaian masalah dari proses adaptasi eksternal dan integrasi internal, yang telah berjalan dengan cukup baik, kemudian diajarkan pada anggota yang baru sebagai cara yang tepat untuk memahami, berfikir, dan menyelesaikan masalah." 
Budaya organisasi melihat nilai pada konteks kelompok, namun tidak akan menafikkan nilai pada aspek individunya, sebab nilai bertitik tolak pada aspek individu itu sendiri. Nilai lebih kepada sesuatu yang abstrak namun disadari oleh setiap individu dalam suatu kelompok, berbeda dengan asumsi yang cenderung tidak disadari. Jika asumsi kultural disebut sebagai landasan dari cara pandang, maka nilai dapat disebut sebagai cara pandang seseorang untuk melakukan dan memutuskan sesuatu. Lahirnya nilai yang kuat memungkinkan manajemen mampu mengorganisir individu-individu dalam organisasi dengan baik. Nilai-nilai ini mencakup strategi, tujuan, dan filosofi dasar yang dimiliki oleh organisasi yang bersangkutan, hal ini biasanya dinyatakan secara tertulis dan menjadi acuan bagi tiap langkah yang dilakukan oleh anggota organisasi (Prihartono, 2012: 169).

Beberapa pembahasan diatas merupakan bentuk dari budaya organisasi, selanjutnya adalah karakteristik budaya organisasi. Menurut Robbins (2002: 279) terdapat 8 karakteristik budaya organisasi, yaitu : (1)Inovasi (innovation), (2)keberanian mengambil risiko (risk taking), (3)Perhatian pada detil pekerjaan (Attention to detail), (4)Orientasi pada hasil (Outcome orientation), (5)Orientasi padaproses (People process orientation), (6)Orientasi pada tim (Team orientation), (7)Agresivitas (Aggressivieness), (8)Stabilitas (Stability).

\section{Organizational Citizenship Behavior}

Organizational Citizenship Behavior atau disingkat dengan OCB lazim dimaknai sebagai perilaku karyawan yang melakukan sesuatu melebihi kewajiban yang telah ditetapkan oleh perusahaan, meskipun tidak ada jaminan mendapat kompensasi secara langsung namun seorang karyawan tetap antusias untuk melakukannya. Sebagaimana dikatakan oleh Robbins dan Judge (2015:19) bahwa perilaku kebebasan menentukan yang bukan bagian dari persyaratan pekerjaan formal pekerja, tetapi berkontribusi pada lingkungan psikologis dan sosial tempat kerja, disebut perilaku kewargaan (citizenship behavior). Dapat diartikan bahwa karyawan yang terlibat dalam OCB tidak akan mengharap reward seperti uang atau bonus lainnya, tetapi dalam OCB sangat mengedepankan tindakan yang bersifat kesadaran untuk berbuat dari setiap karyawan dalam melaksanakan pekerjaan melebihi dari apa yang dibebankan. Seperti pada praktek seorang karyawan membantu teman kerjanya dalam menyelesaikan tugas yang bukan tanggungjawabnya.

OCB lahir dari kesadaran individu untuk berbuat, sehingga tidak diatur dalam bentuk penghargaan formal. Terdapat beberapa bentuk OCB yang dapat diamati dalam tingkah laku individu dalam sebuah organisasi. Menurut Greenberg (2005: 227) organizational citizenship behavior dapat dilihat dari banyak sudutpandang yang berbeda, namun lebih banyak yang membagi atas lima kategori, yaitu sebagai berikut: (1) Altruisme (helping) Seperti sikap sukarela dalam menolong teman kerja yang sedang membutuhkan bantuan. Kesukarelaan tersebut akan dianggap bermanfaat oleh rekan kerja. (2) Kesadaran (conscientiousness) Yakni berusaha untuk tidak pernah meninggalkan pekerjaan, datang tepat waktu jika dibutuhkan, serta tidak menghabiskan waktu untuk maslah peribadi. (3) Kualitas moral yang tinggi terhadap organisasi (civic virtue) Yakni seperti menghadiri rapat dengan sikap yang antusias, merespon setiap informasi yang diberikan. Mengupayakan untuk memperhatikan hal-hal yang penting dalam kemajuan perusahaan. (4) Sikap sportif (sportsmanship) Yakni melaksanakan semua tugas tanpa keluhan serta tidak berperilaku curang. Menjaga agar setiap pekerjaan dapat diselesaikan tanpa membebankan pekerjaan tersebut kepada rekan kerja. (5) Sopan santun (courtesy) Yakni berperilaku baik dan selalu menjaga suasana agar tidak terprovokatori dalam masalah-masalah tertentu. Menghindari terlibat dalam permasalahanpermasalahan yang merugikan perusahaan, sehingga mampu menepis ego pribadi untuk kebaikan bersama.

\section{Komitmen Organisasional}

Menurut Mathis and Jackson (2000: 91) Organizational commitment is the degree to which employees believe in and accept organizational goals and desire to remain with the organization (komitmen organisasional adalah derajat yang mana karyawan percaya dan menerima tujuan-tujuan organisasi dan akan tetap tinggal atau tidak akan meninggalkan organisasi). Komitmen tersebut terwujud dalam keinginan seorang karyawan yang ingin tetap berada pada sebuah organisasi, namun tidak bersifat pasif karena terdapat penerimaan terhadap tujuan sehingga aktif dalam mengupayakan tercapainya tujuan.

Pandangan yang lebih aktif diutarakan oleh Wiener dalam Utaminingsih (2014: 142) bahwa organizational commitment isthe totality of normative pressures to act in a way which meets organizational goals and interest (suatu totalitas yang penekanannya bersifat normative pada aktifitas sebagai cara mempertemukan tujuan organisasi dengan kepentingan). Kepentingan yang dipegang oleh seorang karyawan dan tujuan organisasi, 
bertemu pada suatu titik, sehingga akan menghasilkan rasa puas dalam bekerja. Pada posisi tersebut terjadi sinergitas antara tujuan organisasi dengan kepentingan karyawan di dalam aktifitas kerja.

Menurut Meyer dan Allen (1991) mengemukakan bahwa ada tiga komponen yang terdapat dalam komitmen organisasional. Pertama adalah ffective commitment, muncu ljika karyawan ingin menjadi bagian dalam organisasi karena kuatnya hubungan emosional pada karyawan dan organisasi. Kedua adalah normative commitment, muncul dari nilai dalam diri karyawan itu sendiri. Karyawan memilih menjadi anggota organisasi berangkat dari kesadaran bahwa komitmen terhadap organisasi merupakan sesuatu yang seharusnya dipertahankan. Selanjutnya yang terakhir adalah continuance commitment, muncul apabila karyawan memilih bertahan dalam sebuah organisasi karena memerlukan gaji atau keuntungan-keuntungan yang lain.

\section{Metode Penelitian}

Populasi dalam penelitian ini adalah seluruh karyawan Bancassuran Spesialis BNI Life Insurance Wilayah Makassar. BNI Life Insurance Wilayah Makassar membawahi 10 kantor cabang utama (KCU) meliputi KCU Makassar, KCU Mattoanging, KCU Bulukumba, KCU Pare-Pare, KCU Sengkang, KCU Kota Palopo, KCU Mamuju, KCU Kendari, KCU Bau-Bau. Peneliti menyebar 103 kuesioner, namun yang kembali hanya 86 kuesioner, dan hanya 80 kuesioner dapat diolah. Teknik pengambilan sampel yang dipilih adalah proportional random sampling. Pada penelitian ini, proporsional random sampling berdasarkan pada jenis kelamin, karena adanya perbedaan yang sangat mendasar antara laki-laki dengan perempuan dalam melayani pelenanggan. Kecenderungannya adalah perempuan mempunyai kemampuan lebih ramah dan sabar dalam melayani, sehingga penting untuk membedakan sampel sesuai dengan jenis kelamin.

Merujuk pada rumusan masalah dan hipotesis yang dibangun, maka penelitian ini dapat dikategorikan sebagai penelitian kausalitas (Sekaran, 2007). Metode yang dipakai dalam menjelaskan hubungan kausal antar variabel melalui pengujian hipotesa yaitu metode survei (Zikmund et al., 2009). Selanjutnya, penelitian ini bermaksud untuk memprediksi dan menguji teori sehingga, teknik analisis yang digunakan ialah analisis jalur (path analysis) dengan bantuan aplikasi SPSS.

\section{Hasil}

Hasil uji validitas instrumen Budaya Organisasi, Komitmen Organisasional, dan Organizational Citizenship Behavior menunjukkan nilai signifikansi lebih kecil dari $5 \%$, artinya semua item pernyataan instrumen adalah valid dan dapat digunakan pada proses analisis selanjutnya. Hasil uji reliabilitas instrumen Budaya Organisasi, Komitmen Organisasi, Organizational Citizenship Behavior dan Komitmen Organisasional didapatkan nilai Cronbach's Alpha yang lebih besar dari 0,600. Hasil tersebut menunjukkan bahwa semua instrumen adalah reliabel dan dapat digunakan pada proses analisis selanjutnya.

Uji normalitas ini bertujuan untuk menguji apakah residual dalam model analisis jalur mengikuti sebaran normal atau sebaliknya. Hasil yang menunjukkan bahwa nilai residual tersebar secara normal menjadi salah satu indikator persamaan regresi menunjukkan hasil yang baik. Metode yang digunakan untuk menguji normalitas yaitu dengan uji Kolmogorov-Smirnov. Pada residual model dapat dinilai mengikuti distribusi normal jika signifikansi uji Kolmogorov-smirnov lebih besar dari a yang digunakan dalam pengujian. Hasil uji asumsi normalitas dengan normal p-p plot menunjukkan data bergerak mengikuti garis linear diagonal, dapat disimpulkan bahwa residual yang dihasilkan dari analisis berdistribusi adalah normal dan memenuhi asumsi normalitas.

Uji heteroskedastisitas bermaksud untuk menguji apakah pada model path terdapat ketidaksamaan varian dari residual, pada satu pengamatan ke pengamatan lainnya. Apabila varian residual pada satu pengamatan kepengamatan lainnya tetap, maka disebut homoskedastisitas dan jika tidak atau berbeda maka akan disebut heteroskedastisitas. Metode yang dipakai untuk menguji gejala heteroskedastisitas dalam penelitian ini yaitu metode grafik scatter plot. Apabila tampakan data yang berbentuk titik-titik tidak memperlihatkan pola tertentu dan menyebar diatas dan dibawah sumbu $Y$, maka tidak terdapat masalah heteroskedastisitas. Hasil uji heterokedastisitas menggunakan scatter plot menunjukkan gambar titik-titik menyebar secara acak dan tidak membentuk pola tertentu. Hal ini menjelaskan bahwa tidak terdapat indikasi adanya heterokedastisitas pada model yang diuji sehingga asumsi penelitian ini terpenuhi.

Uji lineritas dilakukan dengan tujuan untuk menguji hubungan antara variabel bebas dengan variabel terikat, apakah menunjukkan linier atau tidak. Hasil pengujian model analisis jalur yang baik yaitu dimana relasi antara kedua variabel yang diuji menunjukkan linearitas. Dalam melakukan pengujian linearitas, metode yang 


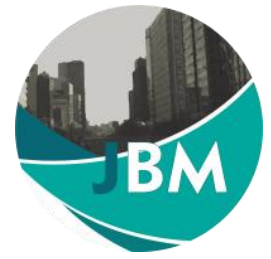

digunakan adalah uji estimasi kurva. Kedua variabel dikatakan mempunyai hubungan linier apabila nilai signifikansi $<a(5 \%)$.

Tabel 1. Hasil Uji Linieritas

\begin{tabular}{ccccc}
\hline Pengaruh & F hitung & F tabel & p-value & Keterangan \\
\hline $\mathrm{X} 1 \rightarrow Y 1$ & 57,063 & 3,960 & 0,000 & Linier \\
$X 1 \rightarrow Y 2$ & 26,853 & 3,960 & 0,000 & Linier \\
$Y 1 \rightarrow Y 2$ & 28,995 & 3,960 & 0,000 & Linier \\
\hline
\end{tabular}

Keterangan: X1 = Budaya Organisasi, Y1 = Komitmen Organisasi, Y2 = Organizational Citizenship Behavior

Sumber: Data Sekunder Diolah (2020)

Hasil uji linieritas dengan uji kurva menunjukkan hubungan antara variabel bebas dan variabel terikat adalah linier yang ditunjukkan dari p-value masing-masing hubungan yang lebih kecil dari alpha $5 \%(0,05)$ sehingga asumsi linieritas terpenuhi.

\section{Hasil Uji Mediasi Variabel Budaya Organisasi terhadap OCB Melalui Komitmen Organisasional}

Berikut merupakan hasil uji pengaruh setiap variabel. Sebelum melakukan uji mediasi maka perlu dilakukan uji pengaruh tiap variabel. Secara keseluruhan variabel Budaya Organisasi berpengaruh terhadap OCB. Begitupun dengan Variabel Komitmen organisasional memiliki pengaruh yang signifikan terhadap OCB. Berdasarkan tabel di bawah, pengaruh paling besar ditunjukkan oleh variabel budaya organisasi terhadap komitmen organisasional, sebesar 0,561 . Sedangkan pengaruh variabel komitmen organisasional terhadap OCB sebesar 0,266 . Pengaruh Budaya organisasi terhadap komitmen organisasional memiliki nilai kofisien jauh lebih besar dari pengaruh komitmen organisasional terhadap OCB.

Tabel 3. Rekapitulasi Hasil Uji Pengaruh Tidak Langsung Budaya Organisasi Terhadap Komitmen Organisasional Melalui Organizational Citizenship Behavior

\begin{tabular}{|c|c|}
\hline Keterangan & Kalkulasi \\
\hline Kofisien Regresi $\mathrm{X} 1 \rightarrow \mathrm{Y1}$ & 0,561 \\
\hline Kofisien Regresi $\mathrm{Y} 1 \rightarrow \mathrm{Y} 2$ & 0,266 \\
\hline Pengaruh tidak langsung $\mathrm{X} 1 \rightarrow \mathrm{Y} 2$ (Uji Sobel) & 1.99156963 \\
\hline
\end{tabular}

Keterangan: $\mathrm{X} 1$ = Budaya Organisasi, $\mathrm{Y} 1$ = Komitmen Organisasi, $\mathrm{Y} 2$ = Organizational Citizenship Behavior

Sumber: Data Sekunder Diolah (2020)

Peran mediasi dari variabel Komitmen Organisasional sebagai variabel mediasi untuk pengaruh budaya organisasi terhadap OCB dapat diketahui dari pengujian menggunakan Uji Sobel. Hasil pengujian menggunakan sobel test menghasilkan nilai sebesar 1.99156963. Sedangkan nilai P- Value yang diuji pada two-tailed probability sebesar 0.04641830 . Nilai P-Value tersebut dibawah nilai signifikansi 5 persen, sehingga hasil menunjukkan bahwa variabel Komitmen Organisasional mampu untuk memediasi pengaruh variabel budaya organisasi terhadap OCB dalam penelitian ini.

\section{Pembahasan}

Hasil uji menunjukkan bahwa komitmen organisasional dapat memediasi pengaruh budaya organisasi terhadap OCB. Artinya bahwa, komitmen organisasional dalam sebuah budaya organisasi melalui komitmen organisasional dapat menstimulus munculnya OCB. Hal ini tentu menjadi penting dalam sebuah perusahaan, sebab dengan munculnya perilaku OCB seorang karyawan maka akan lebih meningkatkan performanya. Karyawan tersebut tidak hanya terdorong untuk menyelesaikan tugasnya sendiri, tapi juga dapat membantu orang lain. Perilaku ini dapat juga disebut sebagai perilaku kerelawanan.

Hasil penelitian ini sejalan dengan hasil penelitian yang dilakukan oleh Arumi, Aldrin, dan Murti (2019) bahwa komitmen organisasional dapat memediasi munculnya OCB dalam sebuah perusahaan. Penelitian Arumi, Aldrin, dan Murti (2019) dilaksanakan pada perusahaan Mobil di jakarta. Dalam penelitian tersebut menjelaskan bahwa terdapat peran penting pada hubungan antara budaya organisasi dengan organizational citizenship behavior di sebuah organisasi.

Komitmen organisasional dapat memperkuat pengaruh budaya organisasi terhadap OCB. Hasil penelitian ini tentu akan memperkuat penelitian sebelumnya. Budaya organisasi yang baik akan menjadi penentu lahirnya 
komitmen organisasi kemudian akan berdampak pada munculnya OCB pada seorang karyawan. Komitmen organisasi dapat dilihat dari perilaku karyawan yang terus bertahan di dalam perusahaan, kemudian menyelesaikan semua tanggung jawabnya dengan baik. Proses tersebut akan menstimulus lahirnya OCB pada karyawan. Lahirnya komitmen karyawan untuk terus melaksanakan kewajibannya dengan konsisten, maka memberi ruang untuk karyawan dalam melakukan hal-hal lain di luar tanggung jawabnya, seperti membantu rekan kerjanya. Karyawan tersebut melaksanakan tugas-tugas di luar tanggung jawabnya dengan maksud membantu tanpa mengharap balasan.

\section{Kesimpulan}

Semua variabel yang diuji dalam penelitian ini memperlihatkan pengaruh signifikan, baik secara langsung maupun secara tidak langsung. Berdasarkan hasil tersebut, pengambilan keputusan strategis terkait pengembangan sumber daya manusia harus mempertimbangkan budaya organisasi yang menjunjung tinggi nilai-nilai luhur organisasi. Mengupayakan agar setiap karyawan merasa puas dalam bekerja agar mampu memberikan dampak terhadap kemauan untuk bekerja lebih giat lagi. Meningkatkan komitmen organisasional karyawan agar karyawan yang kompeten dalam organisasi tetap loyal untuk memperjuangkan tujuan organisasi. Penelitian ini juga dapat memperlihatkan kepada BNI Life Insurance bahwa karyawan yang mempunyai perilaku ekstra peran sangat penting untuk diberi perhatian sebagai upaya menekan keinginan karyawan untuk keluar dari perusahaan (menumbuhkan komitmen).

Saran berdasarkan hasil penelitian ini adalah khusus untuk BNI Life Insurance Wilayah Makassar, agar mampu meningkatkan komitmen organisasional dan menumbuhkan organizational citizenship behavior maka perlu untuk mempertahankan dan meningkat budaya organisasi dan kepuasan kerja karyawan. Perusahaan harus memperhatikan kecenderungan-kecenderungan perilaku karyawan kemudian merespon kecenderungan tersebut dengan perlakuan yang tepat agar karyawan tetap produktif dan terlibat dalam pembentukan budaya organisasi yang diharapkan oleh perusahaan. Dengan cara tersebut diharapkan mampu membuat karyawan dihargai oleh perusahaann tempat mereka bekerja. Selanjutnya, untuk penelitian selanjutnya dengan kajian yang sama, agar peneliti mampu untuk lebih dalam menggali variabel-variabel penelitian yang diteliti sekarang, dengan mengkaji pengaruh setiap indikator dalam tiap-tiap variabel. Sebagai upaya memperkaya metode dalam meneliti, sebaiknya dilakukan penelitian yang menggunakan metode yang berbeda dengan penelitian ini. Selain itu, dalam penelitian ini hanya menguji satu variabel mediasi yaitu Komitmen Organisasional. Tentu akan lebih menambah wawasan lagi apabila variabel mediasi berjumlah lebih satu.

\section{Daftar Pustaka}

Arumi, M. S., Aldrin, N., \& Murti, T. R. (2019). Effect of Organizational Culture on Organizational Citizenship Behavior with Organizational Commitment as a Mediator. International Journal of Research in Business and Social Science (2147- 4478), 8(4), 124-132. https://doi.org/10.20525/ijrbs.v8i4.274

Chiu, Hui-Hsien. (2006). Relationship between Organizational Culture and Organizational Citizenship Behavior; Case Study of Eastern Home Shopping. Grad--Communications Management Chinese. etd-0625107152046

Giri, Endang Eviline; Umar Nimran; Djamhur Hamid; Mochammad Al Musadieq. (2016). The Effect of Organizational Culture and Organizational Commitment to Job Involvement, Knowledge Sharing, and Employee Performance. International Journal of Management and Administrative Sciences (IJMAS), Vol. 3 , No. 04, (20-33)

Greenberg, Jerald. (2005). Managing Behavior in organizations. Fourth edition. Pearson Education. United States of America.

Habib, Salman., Saira Aslam, Amjad Hussain, Sana Yasmeen, Muhammad Ibrahim. (2014). The Impact of Organizational Culture on Job Satisfaction, Employees Commitment and Turn over Intention. Advances in Economics and Business 2( 6 ): 215-222 .

Joseph, Owino O., Francis Kibera. (2019). Organizational Culture and Performance: Evidence From Microfinance Institutions in Kenya. Sega Open. January-march 1-11.

Luthans, Fred. (2005). Organizational Behavior $10^{\text {th }}$ Edition. Penerjemah Vivin Andhika Yuwono, Shekar Purwanti, Th. Arie P., dan Winong Rosari. Andi Yogyakarta 
Mathis, Robert L., John H. Jackson. (2000). Human Resource Management Ninth Edition. South-Western College Publishing- America.

Meijen JVS. (2007). The Influence of Organizational Culture on Organizational Commitment at a Selected Local Municipality. Grahamstown: Rhodes University.

Meyer, John P. dan Allen, Natalie J. (1991). A Three-Component Conceptualization of Organizational Commitment. Human Resource Management Review Department of Psychology, The University of Western Ontario, London Vol. 1 No. 1, pages 61-89.

Momeni, Mandan; Amir Babak Marjani; dan Vajiheh Saadat. (2012). The Relationship between Organizational Culture and Organizational Commitment in Staff Department of General Prosecutors of Tehran. International Journal of Business and Social Science. Vol. 3 No. 13

Prihartono. (2012). Administrasi, Organisasi, \& Manajemen. Penerbit Andi. Yogyakarta.

Robbins, Stehen P.; Timothy A. Judge. (2015). Organization Behavior, 16th ed. Penerjemah Ratna Saraswati dan Febriella Sirait. Salemba Emapt Jakarta Selatan.

Robbins, Stephen P. (2002). Essential of Organizational Behavior, Prentice Hall, inc. Nucahyo Mahanani, ST. MM (editor) diterjemahkan oleh Halida, SE Prinsip-prinsip perilaku organisasi, edisike lima. Penerbit Erlangga Jakarta.

Sahertian, Olivia Laura. (2010). Pengaruh Kepemimpinan, Kepuasan Kerja dan Komitmen Organisasi terhadap organizational citizenship behavior (Studi pada Tenaga Perawat di RSUD dr. Haulussy Ambon). Tesis.Program magister Manajemen Universitas Brawijaya.

Schein, Edgar H. (2004). Organizational Culture and Leadership, Third Edition. Jossey-Bass. United State

Sekaran, Uma. (2007). Research Methods for Business, 4th Edition. Penerjemah Kwan Men Yon. Salemba Empat. Jakarta

Shahzad, Fakhar; Rana Adeel Luqman, Ayesha Rashid Khan, dan Lalarukh Shabbir. (2012). Impact of Organizational Culture on Organizational Performance. Interdisciplinary Journal of Contemporary Research in Business. VOL 3, NO 9.

Sopiah. (2008). Perilaku Organisasional. Penerbit ANDI. Yogyakarta.

Utaminingsih, Alifiulahtin. (2014). PerilakuOrganisasi. UB Press- Malang

Zikmund, W.G.; Babin, B.J.; Carr, J.C.; dan Griffin, M. (2010). Business Research Methods, 8th edition. Australia: South-Western Cengage Learning 